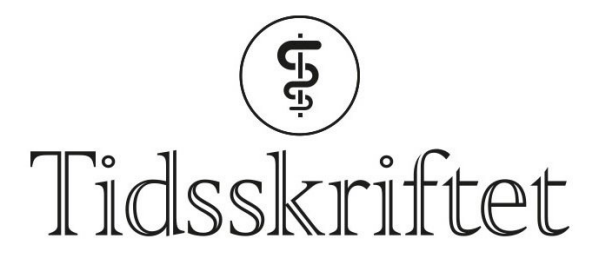

DEN NORSKE LEGEFORENING

\title{
Hvordan oppstår immunologisk hukommelse?
}

FRA ANDRE TIDSSKRIFTER

HAAKON B. BENESTAD

Universitetet i Oslo

Nye studier viser at T-dreperceller kan omdannes til hukommelsesceller. Dette kan få betydning for utviklingen av vaksiner.

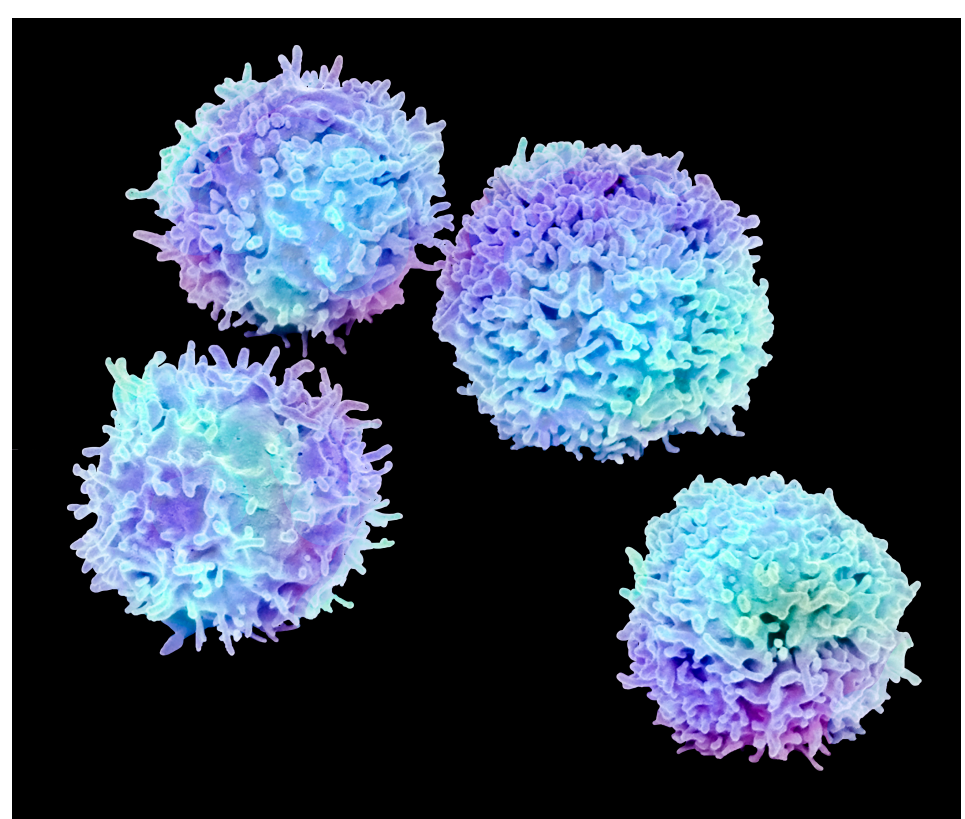

Hvilende T-lymfocytter. Illustrasjonsfoto: Science Photo Library/NTB Scanpix

T-lymfocytter som responderer på en infeksjon, stimuleres til celledelinger og danner effektorceller som kan bekjempe mikroben, og som dør når infeksjonen er over. I tillegg dannes det hukommelsesceller som kan reagere raskt mot reinfeksjon og gi nye effektorceller. Det er uklart om effektorceller og hukommelsesceller oppstår fra naive Tceller uavhengig av hverandre, eller om en mindre del av effektorcellene ikke dør, men blir hukommelsesceller.

To nye studier som nylig er publisert i tidsskriftet Nature, støtter den siste forklaringen. I den første studien ble vaksinasjon med levende virusvaksine mot gulfeber, noe som gir langvarig immunitet, studert ved at reaktive CD8-celler ble merket med hydrogenisotopen deuterium og fulgt over tid (1). I de to første ukene delte både effektor- og hukommelsesceller seg raskt. Etter at viruset var borte, delte hukommelsescellene seg sjeldnere enn én gang i året, men beholdt deler av sin epigenetiske signatur som var felles 
med effektorcellenes tiår etter vaksinasjonen. Deres transkripsjonsprogram var imidlertid mer som hos naive T-celler. Dette indikerer rask immunreaksjon ved reinfeksjon (1). Den andre studien viste at hukommelsesceller stammer fra en gruppe effektorceller som endrer sin epigenetiske signatur fra å ha likhet med de naive cellenes til effektorcellenes og tilbake til de naives mønster (2).

- Kunnskap om hvordan hukommelsesceller oppstår, kan hjelpe utviklingen av mer effektive vaksiner, ettersom målet for alle vaksiner er å gi langvarig beskyttelse mot infeksjon, sier Even Fossum, som er forsker ved Avdeling for immunologi og transfusjonsmedisin ved Oslo universitetssykehus, og som jobber med utvikling av vaksiner. Dette gjelder særlig inaktiverte vaksiner og subenhetsvaksiner, der danningen av hukommelsesceller er mindre effektiv, mener Fossum.

\section{LITTERATUR:}

1. Akondy RS, Fitch M, Edupuganti S et al. Origin and differentiation of human memory CD8 T cells after vaccination. Nature 2017; 552:362 - 7. [PubMed][CrossRef]

2. Youngblood B, Hale JS, Kissick HT et al. Effector CD8 T cells dedifferentiate into long-lived memory cells. Nature 2017; 552: 404- 9. [PubMed][CrossRef]

Publisert: 12. juni 2018. Tidsskr Nor Legeforen. DOI:10.4045/tidsskr.18.0206

(C) Tidsskrift for Den norske legeforening 2020. Lastet ned fra tidsskriftet.no 